\title{
Transatlantica
}

Revue d'études américaines. American Studies Journal

$1 \mid 2018$

Slavery on Screen / American Women Writers Abroad: 1849-1976

\section{Percival Everett: Theory, philosophy and fiction}

ERIAC (EA 4705), Rouen University

May $2^{\text {nd }}$ and $3^{\text {rd }} 2019$

\section{Anne-Julie Debare}

\section{(2) OpenEdition}

\section{Journals}

Electronic version

URL: https://journals.openedition.org/transatlantica/11500

DOI: 10.4000/transatlantica. 11500

ISSN: 1765-2766

\section{Publisher}

Association française d'Etudes Américaines (AFEA)

\section{Electronic reference}

Anne-Julie Debare, "Percival Everett: Theory, philosophy and fiction", Transatlantica [Online], 1 | 2018, Online since 25 September 2019, connection on 03 February 2023. URL: http://

journals.openedition.org/transatlantica/11500 ; DOI: https://doi.org/10.4000/transatlantica. 11500

This text was automatically generated on 3 February 2023.

\section{cc) (†)}

Creative Commons - Attribution-NonCommercial-NoDerivatives 4.0 International - CC BY-NC-ND 4.0

https://creativecommons.org/licenses/by-nc-nd/4.0/ 


\section{Percival Everett: Theory, philosophy and fiction}

ERIAC (EA 4705), Rouen University

May $2^{\text {nd }}$ and $3^{\text {rd }} 2019$

Anne-Julie Debare

1 This symposium, organized by Anne-Laure Tissut (ERIAC, EA4705), echoes and prolongs the reflections on Percival Everett's work sparked by a conference that took place in Rouen in 2013 in the presence of the author. While the previous symposium investigated questions about the American West's identity and representations, this year, Everett scholars sought to highlight the theoretical and philosophical influences perceptible in the work and how they inform Everett's artistic process as well as the genesis of his novels.

2 French, American and German Everett specialists investigated the use of philosophy and theory as artistic material per se as well as discourses to be prolonged, responded to or thwarted. More broadly, determined structures such as narratives and languages were also under scrutiny during this particularly stimulating conference on one of the most innovative contemporary American novelists.

Everett's literary response to ontological conundrums, binarism and the limitations of theory

3 For Michel Feith (Nantes University), Everett's novels shed light on the "deeply philosophical questions" inherent in the representation of animals by blurring the boundaries between the realm of animals and men. Taking on animal representations and metaphors to tackle deeply human ethical, intimate or political situations, Everett's novels use animal categorization and totems while never fully relying on them and sometimes parodying them thus "shattering definite forms against taxonomies and limiting possibilities". According to Feith, Everett's novels put the emphasis on "the imperative to know oneself as animal", the importance of "playing along with one's categories, becoming oneself again by mudding identification". Anthony Stewart (Bucknell University, USA) argued that, by showing Ishmael Kidder's 
internal conflicts and his experiments with how we make meaning, The Water Cure invites the reader to wonder what kind of moral vocabulary is available to us. Indeed, according to Stewart, The Water Cure's "lack of resolution" and the inconclusiveness of Everett's writing reveal both the intrinsic inadequacy of language and conventional divisions. In line with skepticism and pragmatism, Everett's novel generates a "productive frustration" by shaking perceptual limits and the categories we draw from them, and invites the reader to "embrace [inconclusiveness] as significant in itself" and to "consider its value over distractive certainty" as it forms "a basis for common comprehension".

4 Judith Roof (Rice University, USA) offered a reading on Erasure, presenting it as a literary response to Journalist Chuck Stone known for his sustained fight against "the conceptual limitations of race conceived as an opposition as well as the conditions such thinking produces and perpetuates". Roof pointed out how, prolonging Stone's theoretical basis and his enlightening take on a binarism that still pervades the contemporary "identity politics," Erasure seeks to baffle "the caucaso-centrism of the reader and his underlying racist projections while reading" and thus "sunders and disperses categorical binaries into the infinite multiplicities that subtend speaking subjects". In her presentation Christelle Centi (Rennes 2 University) argued that Percival Everett's novel Watershed is the locus of a tension between attempts at detachment toward Native American violent History and a collective trauma presented in an oblique manner, a tension that enables the text "to constitute and legitimize a marginal intertextuality of Native history, as well as foreground the colonial logocentrism of the United States". Centi showed how the novel points out "the reification of Native American cultures, as well as the linguistic strategies put in place by the fictional tribe of the book to counteract this hegemony" and how Watershed "ties language, and the institutional knowledge derived from it, back to the buried history of the land". Shannon Klein (Rice University, USA) offered a reading of Everett's later works including So Much Blue, American Desert, and Half an Inch of Water in light of the theory of second wave feminism, including the work of Simone de Beauvoir, Germaine Greer, and Betty Friedan. Klein leaned on considerations about the nature of heterosexual relationships and reflections on matrimony and gender struggle within marriage, to examine the nature of the protagonists' sexual and romantic relationship, thus highlighting how Everett's writing "lends a needed nuance to both theories and stories".

5 Annie Lowe's (Rice University, USA) presentation shed light on Everett's exploration of logical and mathematical structures to grapple with questions of identity and logic. Lowe argued that, in Percival Everett by Virgil Russell, the text prolongs Gottlob Frege's theory according to which arithmetic is yet a mere extension of logics and "spin[s] the logical question of identity around a fictional narrative" in order to "plot a quest to make sense of the limits of sense through its own entirely contingent and entirely necessary form as a story". In her reading of American Desert Melissa Bailar (Rice University, USA) put forward the literary investigation on the limitation of reason in apprehending and making sense of the body in death. The novel's exploration of the failures of religion and science to grasp death, "suggests that discursive ways of approaching death and the body might yield more than illusory rationality". The defamiliarization of the reader's notions of death and laughter to "confront the 
unknown and the fear of it" may well constitute these other discursive forms of knowledge.

\section{Questioning determined structures: subverting genres and language}

Sylvie Bauer (Rennes 2 University) offered a sharp reading of Assumption and showed how detective novel stereotypes are used by Everett as a matrix that meets the reader's expectations related to the whodunit to better thwart them and open up the determined structure of the genre. She demonstrated how on a larger scale this process exceeds generic implications and extends to language itself. Bauer showed how in Assumption, Everett's writing creates an "effet de flottaison" that brings the reader to investigate diegetic truth but also "to tackle questions on the making and unmaking of meaning". Johannes Kohrs (Freie Universität Berlin, Germany) posited that in Everett's crime fictions the dead bodies' "ontological precariousness corresponds with the epistemological instability that characterizes Everett's storytelling at large". Kohrs sought to foreground Everett's "anti-binary and counter-conventional approach to identity and literary representation" and, to do so, showed how those "dubious bodies" in Everett's fiction are a way to "open up a critical running-commentary on consensual notions of identity and responsibility, relentlessly debunked by Everett's writing.

Derek C. Maus (State University of New York at Potsdam, Germany) showed how Menippean satire provides an analytical strategy that offers interesting interpretive insights on Everett's work, a work that always strives to reassign in fine the meaningmaking process to the reader. Maus offered a close reading of Everett's most recent work The Book of Training by Colonel Hap Thompson of Roanoke, VA, 1843: Annotated From the Library of John C. Calhoun, arguing the novel to be "a wholly Menippean work, that satirizes not only the bigoted logic that underpinned American chattel slavery, but also the ongoing political/philosophical/social legacy of the Confederacy represented by Calhoun's marginalia within Thompson's fictional 'text on the training of our black animals"'. Clement Ulff (Rouen University) posited that fragmentation and the blurring of boundaries between fiction and autobiography at work in Erasure prompt the readers to reconsider their mode of interpretation as they are "teased toward a proliferation of readings in the text and beyond" to reach a "clarity [that] can be born from fragmentation and obscurity".

Bren Ram (Rice University, USA) offered a reading of Erasure and Percival Everett by Virgil Russel through Roland Barthes' The Pleasure of the Text and proposed "an exploration of the erotic in narrative, begging the question of desire and what animates readers to enter and complete texts in the first place". Ram showed how the "frustration of narrative closure" and the "perversion of narrative expectations" at work in Everett's novels drive both the narrative structure and the reader's response and pleasure in the act of reading.

During the symposium, documentary maker Alexandre Westphal also presented his ongoing documentary project about Percival Everett's work, Land of stories (provisional title). Weaving together images of interviews, archives, as well as readings of excerpts performed by a fictional doppelganger of the novelist, "which should resound with the recursive figure of the double in his work," the film will lean on Everett's interest for satire and pastiche. Westphal tackled preoccupations proper to filmic representation, such as the possibility to translate a style or a writer's imagination into pictures. 
10 These stimulating presentations led to fruitful and jaunty exchanges over coffee breaks and lunches served in the course of this two-day conference. It was a pleasure witnessing the exchanges and the relationships forged during this symposium, which also fostered the thriving collaboration between Rice University scholars and Rouen University.

11 Link to the programme: http://eriac.univ-rouen.fr/percival-everett-theoryphilosophy-and-fiction/

INDEX

Subjects: Actualité de la recherche

\section{AUTHOR}

ANNE-JULIE DEBARE

Rouen University 